Hertwig, he decided to devote himself to zoology. After graduating, several university posts were held by him in Munich until I9I2, when he was appointed Weissman's successor as professor of zoology at Freiburg. Here he taught for six years, finally moving to Breslau in the autumn of 1918 to become Director of the Zoological Institute in succession to Kükenthal.

A many-sided naturalist, Doflein published work on crabs, ants and Bdellostoma as well as his numerous important papers on the protozoa. The first edition of his text-book appeared in I9oI under the title" Die Protozoen als Parasiten und Krankheitserreger." The second edition five years later was the first to be known as the "Lehrbuch der Protozoenkunde," and it included descriptions of free-living as well as parasitic protozoa. In collaboration with his friend Richard Hesse, Doflein recorded their observations on living animals in a popular book entitled "Tierbau und Tierleben," which appealed to a large circle of readers. In addition to this, he wrote popular books on three scientific expeditions undertaken by him-to the West Indies, Japan, and Macedonia. The last, on his Macedonian travels, published in I92r, is illustrated with his own water-colour sketches.

In the early part of 1923 , owing to continued illhealth, Doflein resigned his appointment in Breslau, and he died of pneumonia on August 26, 1924. Thus was tragically cut short a life of great achievement, for not only did he contribute much to biology himself but he also attracted many students to his laboratories, where they were allowed to follow their own lines of research, although always sure of his help in difficulty. His liberality and broad-mindedness were indeed part of that artistic temperament which delighted all with whom he came in contact.

The Chemiker Zeitung of November 4 records the death, on October 25, at the age of seventy-two, of Dr. Carl Huggenberg, one of the pioneers among German public analysts. Huggenberg's name is associated with the well-known Analytical Institute founded by him at Chemnitz, where most of his public work was carried out. Born of Swiss parentage at Winterthur, he studied first at Zurich and later at Würzburg, where he became assistant to J. Wislicenus, and graduated in 1876 . During the following three years he held an official appointment as analyst of foodstuffs in the Canton of Zurich. This special branch of applied chemistry was still in its infancy at that time, but in all the German towns, associations were being formed with the object of fighting against the adulteration of food. In 1882 , the association which had been founded five years previously at Chemnitz by L. Friedrich, offered Huggenberg the direction of its laboratory. Here he found full scope for the development of his natural powers. His analytical skill, his comprehensive knowledge of chemistry, and his practical insight into the needs of industry and commerce were invaluable assets to him, and his opinion on technical matters was soon widely sought. His interest in technology led him to make numerous valuable investigations in oils, fats, and soaps, and he made numerous contributions to scientific literature on the refractometry of soap-fats, the recovery of waste fat, and on soap analysis. Until 1902 he aiso held the post of food controller at Chemnitz. In I9ıo he retired to Zurich.

\title{
Current Topics and Events
}

The Fishery Board of Scotland recently issued a notice to fishermen and others directing attention to the protection afforded to the grey seal under the Grey Seals Protection Act of 19I4, which lays open to a penalty of $5 l$. any person taking, killing, or wounding grey seals during a close season, October I-

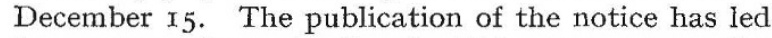
to correspondence in the Scottish newspapers, the protection of this seal being condemned on the ground that it is increasing in numbers and is responsible for the destruction of some of the Hebridean cod fisheries. The weight of the evidence, however, seems to indicate that the grey seal is very rapidly decreasing in numbers on the west coast, and that the constant slaughter of the young in certain breeding haunts, their pelts being sent in considerable numbers to furriers in Glasgow, threatens the existence of the species in these waters. As regards the destruction of fisheries, the assertion is made that dog-fish and not cod form the diet of the seal, and that the destruction of seals and consequent increase of dogfishes are responsible for the deficiency of cod. The point is an important one, which is left undecided by the assertions of the correspondents. It might readily be settled by the examination, by an expert in fragmentary fish remains, of a few series of stomach contents taken at appropriate seasons.
The Field Museum of Natural History, Chicago, has arranged a series of twelve free programmes of moving pictures, with occasional lectures, illustrating natural history subjects, for children on Saturday mornings from October to December. The subjects include "Wild Animals I have known," by Mr. Ernest Thompson Seton, Capt. Kleinschmidt's " Polar Adventure," Theodore Roosevelt's " Visit to a Bird Reservation," and a number of films illustrating particular facts and aspects of zoology, botany, and geology. At each entertainment a little printed " museum story" is given to each child. This story gives, in simple language, some brief facts about the men, animals, and plants seen in the pictures, and directs the child to the case or cases in the Museum in which they are exhibited. By directing attention to the permanent exhibits in this way, opportunity is afforded to the child to crystallise the general impressions and information gathered from the films, and the real educational value of the scheme is thereby enormously enhanced. It surely is more than a series of entertainments, as the programmes are described on the syllabus. The experiment will be watched with great interest not only by those who believe in the vast potentialities of museums in education, but also by those who are convinced of the possibilities of the cinematograph as an aid in the same field. 